\title{
Brottslighet och brottskontroll i Finland och de andra Nordiska länderna: Banbrytare eller eftersläntrare? ${ }^{1}$
}

\author{
Av Per Ole Träskman ${ }^{2}$
}

\begin{abstract}
The Finnish Society for Criminal Law and Criminology (Kriminalistföreningen $i$ Finland) was established 1934. A jubilee seminar was arranged in Helsinki in April 2015 to celebrate the fact that 80 years have passed since its establishment. The current article is an elaborated version of the paper the author presented at the seminar.

The article examines the development of criminal law and policy in Finland and the Nordic countries more generally from the beginning of the 20th century to the present. This period is divided in several shorter units: the initial decades of the 20th century; the 1930s; the wartime years of 1939-1945; the post-war period to the 1950s; the emergence of Nordic concordance and the time of Nordic prosperity until the end of 1990s (a period which gave rise to the internationallyrecognized concept of "Nordic exceptionalism"); the period of increasing criminal repression during the first decade of the 21st century; and finally the period of decreasing incarceration which began in 2005.

The article focuses on an assessment of how progressive the Nordic criminal and control policies can be considered in an international context. Have the Nordic states been forerunners or stragglers? The answer remains unclear or, maybe, "both and", with different answers during different historical periods."
\end{abstract}

\section{Var finns Norden?}

Slutet av 1800-talet och början av 1900-talet var en ideologisk brytningstid inom straffrätt och brottslighetskontroll. Det var tiden då den positiva straffrättsskolan fick sitt genomslag. ${ }^{3}$ År 1882 formulerade Franz von Liszt sin straffteori i det s.k. Marburg programmet. Enligt detta låg straffets syfte och berättigande i vad man kunde uppnå genom de straffrättsliga påföljderna. Nyckelorden var Sicherung, Besserung und Abschreckung.

* Title in English: Crime and Crime Control in Finland and the Other Nordic Countries: Forerunners or Stragglers. 
I Italien fanns Enrico Ferri som i samma anda som Liszt förklarade att valet av påföljden för ett brott handlade om ,, a choice between various remedies, in order to find those which will have the greatest effect on the various causes that produce the individual crime“. Ferri byggde sin uppfattning på empiriska studier av de nationella straffsystemen i Europa och brottslighetens utveckling i dem. De nationer som ingick i hans studier var Italien, Spanien, Frankrike, Belgien, Tyskland (och Preussen), England och Österrike. Jag har inte kunnat finna en enda hänvisning till ett nordiskt land och därför framhållit att detta är ett memento: Norden är inte internationellt sett ett särskilt uppmärksammat område i forskningen om Europas straffrättshistoria - internationellt sett upptäcktes den nordiska straffrätten och de nordiska kriminalvetenskaperna egentligen först efter Andra världskriget. ${ }^{4}$ Men visst fanns det straffrätt, kriminalpolitik och brott också i de nordiska länderna före detta.

\section{2. "En brottslighetens flodvåg" i Finland på 1930-talet}

Den 7-13 januari 1934 ordnades en antibrottslighetsvecka i Helsingfors. De föredrag som hölls under veckan publicerades i en bok med titeln "Brottsligheten och möjligheterna för dess bekämpande". ${ }^{5}$ Hälsningstalet hölls av dåvarande justitieministern Eric J. Serlachius och detta kännetecknades, liksom de flesta föredragen, av en svartsyn. Man menade sig se "en brottslighetens flodvåg" och krävde den mest energiska kraftansträngning för skyddandet av samhället mot faror som "från de asociala elementens" sida hota detsamma. Minister Serlachius var starkt bekymrad över den tilltagande brottsligheten och glad för det aktuella medborgarintiativet för dess bekämpande:

Tack vare prisvärt initiativ av ett antal för vår folkuppfostran och för samhällelig hygien nitälskande personer att försöka bringa allmänheten till insikt om vådorna av att inte hejda den nedslående utveckling, den tilltagande brottsligheten under de senaste decennierna innebär, har denna propagandavecka för brottslighetens bekämpande, som i dag tager sin början, anordnats.

Ett gott exempel på tonen i föredragen är professor och friherre R.A. Wredes föredrag om brottsligheten och dess bekämpande. Rabbe Axel Wrede (1851- 1938) var en av dåtidens mest kända rättslärda i Finland. Han var professor i civillagfarenhet och romersk rätt, och senare också professor i civilprocessrätt vid Helsingfors universitet. Han hade varit rektor för Helsingfors universitet och kansler för Åbo Akademi. Han åtnjöt ett stort internationellt erkännande som processualist och detta ledde till att han blev hedersdoktor vid Lunds universitet, vid universitetet i Hamburg och vid universitetet i München. Han var politiskt aktiv och han 
verkade också som vice ordförande i senatens justitiedepartement (som idag motsvaras av Högsta Domstolen). Jag citerar en passus ur hans föredrag:

Ett samhällsont, som först på senaste tid och ej ens ännu i tillräckligt hög grad ådragit sig uppmärksamhet, är den enormt stegrade brottsligheten i landet. [...] Denna oerhört starka brottslighet, som ej har sitt motstycke bland Europas civiliserade nationer, utgör inte blott en skamfläck för Finlands folk vilken nedsätter dess anseende hos andra folk. Den innebär även en allvarsam fara för vårt folks moral och för hela dess kultur. Ja, den kan t.o.m. äventyra landets självbestånd såsom rättsstat och västerländsk kulturstat, måhända även som självständig stat över huvud. ${ }^{6}$

Detta var tidsstämningen då Kriminalistföreningen i Finland grundades år 1934. När det gäller straffideologi var tidpunkten präglad av den sociologiska skolans tankar med stark betoning av individualpreventionen och dess vård- och behandlingsideologi. Också samhällsskyddet var i fokus, medan den äldre klassiska skolan som hade varit dominerande sedan början av 1800-talet allt mer hade fått vika. De nya ideologiska tankarna var inspirerade av Franz von Liszt och hans Marburg program från år 1882. Mycket inspirerade av detta grundades kriminalistiska föreningar i de nordiska länderna. I Norge redan år 1892, i Danmark 1899, i Sverige 1911 och sedan i Finland 1934.

Vad som betonades när det gällde kunskapen om brottsligheten var forskningens betydelse. Men denna forskning var bara i liten grad straffrättslig, knappast alls sociologisk, men desto mera biologisk, psykiatrisk och genetisk. Flera av tidens ledande brottsforskare menade att den enda rätta kriminologin var psykiatrin. När det gällde lagreformer handlade det framför allt om att skapa nya påföljder. Bland dem fanns villkorligt straff (för tillfällighetsbrottslingar) men framför allt påföljder för att oskadliggöra återfallsbrottslingarna och de andra som uppfattades vara samhällsfarliga. Man tog i bruk tidsobestämda påföljder som internering och förvaring, man införde tvångssterilisering och ibland också tvångskastrering samt nya uppfostrande påföljder särskilt för unga brottslingar. Inspiration och förebilder söktes ofta i Tyskland, ibland t.om. med tydliga nationalsocialistiska förtecken. Degenerationsläran var omhuldad och den gjorde grogrunden för att använda sterilisering som en social kontrollmetod. ${ }^{7}$

Några av de mest framträdande kriminalpolitikerna var starka anhängare av rasbiologin. Detta var fallet med Olof Kinberg i Sverige och Harry Federley i Finland. Båda höll föreläsningar under antibrottsveckan $1934 .{ }^{8}$ Kinberg hävdade ofta som sin uppfattning att det var det biologiska arvet och inte miljön som var betydelsefull ifråga om brottslighet: 
Såsom varje praktisk kriminolog vet finnes det individer hos vilka den naturliga tendensen till asociala eller antisociala handlingar är så stark, att de alltid komma att begå brott, likgiltigt i vilken miljö de befinna sig. Det är brottslingar av denna typ som Lombroso kallade rei nati, födda förbrytare. 9

I en annan av hans skrifter kan man läsa:

I vissa fall måste miljön betraktas som en funktion av anlaget. Den antisocialt disponerade har sålunda alltid tillfälle att förskaffa sig den dåliga miljö han eventuellt behöver, för att hans dåliga anlag skola nå sin fulla utveckling. ${ }^{10}$

Harry Federley var extra ordinarie professor i genetik vid Helsingfors universitet. Han ville tillämpa genetiken på rashygien. I en uppmärksam artikel i tidskriften Nya Argus lade han fram "bevis" för att de demokratiska idealen saknade varje vetenskapligt stöd. Människorna är inte alls lika; och dessutom är skillnaden mellan en av den moderna kulturens ledande personligheter och den australiska vilden vida större än steget från vilden till människoapan. Även inom Europas befolkning fanns enligt honom åtskilliga individer som inte alls höjde sig över vildens nivå. Demokratin skulle enligt Federley ge dessa mindervärdiga element samma inflytande som de högtstående. Dessutom är mindervärdigheten inte alls en produkt av sociala faktorer, utan det är följden av en ogynnsam kombination av arvenheter. ${ }^{11}$

Det var därför också konsekvent att både Federley och Kinberg förespråkade tidsobestämda straff, stränga kontrollåtgärder mot lösdrivare ${ }^{12}$ och alkoholmissbrukare $^{13}$ samt tvångssterilisering. Det följande är ett citat ur en av Kinbergs texter:

Då samhällsparasiternas relativa antal [...] måste vara minst lika stort som förr, kan det inte råda något tvivel att denna kategori individer numera i långt större utsträckning leva sitt liv okontrollerat ute i samhället. Detta är icke utan betydelse för antalet födda undermåliga. Ty även om sådana individer endast i ringa utsträckning bilda familj, så är det en känd sak att barnafäderna till de talrika undermåliga barn som födas av sinnesslöa kvinnor litet varstädes ute i bygderna företrädesvis tillhöra just detta klientel. Om deras insats i barnalstringen är kvantitativt mindre betydande, så väger den så mycket tyngre genom sin undermåliga beskaffenhet. ${ }^{14}$

Om man i grova drag beskriver brottslighetskontrollen och kriminalpolitiken under 1900-talets första decennier kan man som överskrift sätta "rädsla för en våg av brottslighet" och samtidigt "reform och optimism". ${ }^{15}$ Optimismen kom genom tilltron till nya forskningsresultat som också skulle leda till nödvändiga reformer och framgång. Det handlade om ökad effektivitet, möjligheter att minska brottså- 
terfall och därigenom öka samhällsskyddet. Individualprevention, individualiserad vård och behandling samt ett starkt samhällsskydd var ledstjärnor. ${ }^{16}$

\section{Krig och efterkrigstid}

Andra världskriget berörde de nordiska länderna, men på olika sätt. När kriget började hösten 1939 förklarade alla de nordiska länderna att de var neutrala. I Finland varade neutraliteten tre månader, i Danmark och i Norge ett drygt halvt år, medan Sverige förblev neutralt hela kriget igenom. Krigets påverkan på samhälle och liv var också minst i Sverige. I de tre andra länderna var det mer dramatiskt. Danmark ockuperades av Tyskland nästan utan motstånd, men där fanns en underjordisk motståndsrörelse under hela kriget. Norge ockuperades av Tyskland efter motstånd, medan Finland förde krig mot Sovjetunionen till en början självständigt och senare allierat med Tyskland. Vid krigets slut förde Finland krig mot de tyska trupperna, inte minst i Lappland. Kriget krävde dödsoffer. I Finland räknar man med cirka 85.000 krigsoffer, i Norge cirka 10.000 och i Danmark omkring 1.500. Sverige som stod utanför kriget klarade sig utan egentliga krigsoffer.

Kriget påverkade allt, också brottsligheten och kontrollen av brottsligheten. Under början av 1980-talet undersökte och granskade en nordisk forskningsgrupp olika aspekter av brottslighet och kontroll i Norden under det andra världskriget. Forskningsgruppens resultat publicerades i en antologi som utgavs av Universitetsforlaget i Norge, "Krig och moral. Kriminalitet og kontroll i Norden under andre verdenskrig". ${ }^{17}$

Det finns inte utrymme i detta sammanhang att granska frågorna om brottslighet och kontroll under det andra världskriget närmare. Då det gäller brottsligheten är bedömningen svår på grund av att uppgifterna är begränsade och bristfälliga. Något olika tolkningar har därför presenterats. Man har å ena sidan påstått att kriget stärker moralen och därför minskar brottsligheten. Å andra sidan har man uppställt antagandet att kriget är demoraliserande och att brottsligheten därför ökar. Det senare förefaller vara riktigt när det gäller Norden under det andra världskriget - åtminstone med avseende på vissa typer av brott framför allt egendomsbrott och brott mot reglementeringsbestämmelser. ${ }^{18}$

Särskilt för Finlands del försvåras en bedömning av brottsutvecklingen och kriminalitetskontrollen av att en stor del av fallen behandlades vid fältkrigsrätterna utan noggrannare dokumentation. Vad som är uppenbart och anmärkningsvärt för Finland är under alla omständigheter det stora antalet dödsstraff - också det omtvistat. ${ }^{19}$ Detta är en svart parentes i den positiva utvecklingen och avvecklingen av dödsstraff i Finland som inleddes redan $1826 .{ }^{20}$ 
Av naturliga skäl togs inte några stora initiativ för kriminalpolitiska reformer under andra världskriget. De fick vänta till efter kriget, då nya utmaningar kom till: en omfattande ökning av brottsligheten i alla nordiska länder.

\section{Brottsligheten ökar - liksom det nordiska samarbetet}

Efter 2. Världskrigets slut ökade brottsligheten starkt i alla nordiska länder. Detta var ett genomgående budskap i de nationella rapporterna om brottsutvecklingen som presenterades vid det IX nordiska kriminalistmötet i Helsingfors år 1984 det år då Kriminalistföreningen i Finland firade sitt 50 -års jubileum. ${ }^{21}$ Kriminalitetsutvecklingen i de nordiska länderna visar på många gemensamma drag, men den är inte helt identisk. Förklaringarna till ökningen är de gängse: ökad industrialisering, ökad urbanisering, ökad geografisk och social rörlighet, ökad alkoholkonsumtion och med tiden också ett ökat missbruk av andra rusmedel. Till detta kom växlande perioder av stark ekonomisk växt och ekonomisk stagnation. ${ }^{22}$

För Norges del beskrevs kriminalitetsutvecklingen efter 2. Världskriget vid kriminalistmötet år 1984 på följande sätt:

Fra etterkrigsårene og frem til i dag (1984) har vi hatt en kraftig økning i registrerte kriminalitet. Men dette er ikke det eneste som har endret seg i perioden. Levestandarden er hevet og samtidigt kravene til komfort, materielle goder og livsinnhold. Det er imidlertid ikke bare de positive variabler som viser stigning, men også de negative. F.eks. økte krav og utstøtning fra skole og arbeidsliv, økt behov for ulike trygder og stødsanordninger, stigende selvmordsfrekvens og økt alkoholkonsum $[\ldots]$. $^{23}$

Samhällsförändringarna var betydande med direkta konsekvenser för brottsligheten och brottslighetskontrollen. I den nationella finska rapporten om brottslighetsutvecklingen 1950-1982 beskriver Patrik Törnudd detta bl.a. på följande sätt:

Åren 1950-1982 inrymmer en period av unika strukturförändringar i Finland. Övergången från agrarsamhälle till industrisamhälle skedde senare och snabbare i Finland än i de övriga nordiska länderna. 1960-talet och början av 1970-talet kännetecknas av en exceptionellt omfattande inre migration till städerna och industriorterna i Syd-Finland. Samtidigt nådde de stora födelsekohorterna som föddes efter kriget brottsintensiv ålder. Inverkan av dess stora samhällsförändringar kommer klart till synes i brottslighetsutvecklingen.

I första hand kan strukturförändringarna väntas öka antalet brottstillfällen. För det stora flertalet brottsarter gäller att tätorter erbjuder fler möjligheter att begå brott än på landsbygden. Detta gäller in blott "tillfällen" i ordets mest konkreta bemärkelse: antal stöldobjekt eller tillgång på supkamrater att råka i slagsmål med. Med tilltagande urbanisering och ekonomisk växt följer också ofta att den genomsnittliga bevakningsintensiteten per brottsobjekt minskar och att kontrollen av risksituationer överlag försvagas. ${ }^{24}$ 
I alla dessa uttalanden ser vi mer eller mindre tydligt beskrivningar som ingår som centrala element i den kriminologiska teori som framför allt har utvecklats av Lawrence E. Cohen och Marcus Felson, "the routine activity theory" (1979). ${ }^{25}$ Jag ska inte utveckla denna aspekt, utan bara ställa frågan om vad den ökade brottsligheten innebar för den nordiska kriminalpolitiken och för strafflagstiftningen. Det korta svaret blir: Till en början inte så mycket alls! Man fortsatte i de gamla fårorna. Vård- och behandlingstanken var fortfarande dominerande i Sverige, allt medan man fortsatte att utarbeta en ny strafflag för att ersätta den gamla strafflagen från 1864. Här hade också idén om samhällsskydd ett starkt fotfäste. Symptomatiskt för detta var att det förslag som lades fram år 1956 av Strafflagsberedningen. ${ }^{26}$ Enligt betänkandet skulle den nya lagen heta "Skyddslag" och i förslagen till den undvek man medvetet att använda benämningen straff. Fråga var ju i grunden om en lag som handlade om åtgärder för att skydda samhället.

I Norge och i Finland hade allmänpreventionen fortfarande det starkaste stödet, men också här infördes olika typer av tidsobestämda sanktioner framför allt för återfallsbrottslingar och för brottslingar som uppfattades vara personfarliga. I Danmark var man mer inspirerad av individualpreventiva tankar, men i praktiken var man ofta benägen att välja den lösning som föreföll vara den mest praktiska.

\section{En ny ideologisk brytningstid}

Den kriminalpolitiska utvecklingen under decennierna efter 1950 kan kort beskrivas med orden "besvikelse, ny riktning och nya alternativ". ${ }^{27}$ Besvikelsen var en följd av att de tidsobestämda sanktionerna inte hade visat sig vara så effektiva som man hade förväntat sig och inte heller de straffskärpningar som följde en starkt ökande brottslighet. Hela straffsystemet kritiserades, också med hänvisning till rent abolitionistiska tankar. Det blev en ny ideologisk brytningstid.

Det fanns flera orsaker till detta och inte bara sådana som berodde på kriminalitetsutvecklingen. De nordiska länderna utvecklades alla till välfärdsstater och detta gav utrymme också för kriminalpolitiska kontrollsträvanden i en mer liberal riktning. Samhällsplanering blev ett nyckelord och man var överlag optimistisk över vad man kunde uppnå genom detta. Kriminalpolitiken uppfattades som en del av kontrollpolitiken och kontrollpolitiken var en del av den mer generella samhällspolitiken. Den kriminologiska forskningen gjorde sitt intåg i de nordiska länderna och gav en vetenskaplig grund för bedömning av vad som verkar och vad som inte verkar. Stora delar av politiken radikaliserades och detta ledde också till att det också på kriminalpolitikens område uppstod massrörelser som i form av aktiva grupper ville förbättra bl.a. fångarnas förhållanden. De viktigaste av dessa var KRIM, KRUM, KROM organisationerna som var intresseorganisation- 
er för fångar och aktiva i alla nordiska länder och som verkligen lyckades reformera vissa av de hårda förhållandena för intagna fångar. ${ }^{28}$

\section{6. "The Golden Age of Nordic Cooperation" och "The Nordic Exceptionalism"!}

Under denna period utvecklades också det nordiska samarbetet betydligt. Sedan länge fanns de nordiska kriminalistföreningarna och deras samarbete, de nordiska juristmötena samt mer officiellt Nordiska Rådet och Nordiska Ministerrådet. Nordiska Samarbetsrådet för kriminologi grundades 1962 med stort och starkt stöd från alla nordiska regeringar och en engagerad uppslutning bland kriminologer i alla nordiska länder. Förarbeten för en gemensam nordisk lagstiftning avseende vissa straffrättsliga frågor utarbetades dels i samarbete mellan justitieministerierna i de nordiska länderna och mer speciellt av den Nordiska straffrättskommittén. Också på kriminalvårdens område var samarbetet aktivt liksom också mellan åklagarmyndigheterna. Nordisk Tidsskrift for Kriminalvidenskab var ett naturligt forum för artiklar inom straffrätt, kriminalpolitik och kriminologi när innehållet hade ett gemensamt nordiskt intresse. ${ }^{29}$

Jag har kallat denna period för "The Golden Age of Nordic Cooperation". Med avseende på kriminalpolitiken och kontrollen av brottsligheten var det under denna period som utvecklingen ledde till det som internationellt har kallats "den nordiska exceptionalismen" ${ }^{30}$ Detta uttryck täcker över det faktum att fångtalet $\mathrm{i}$ Norden har hållits lågt som en följd av ett relativt lågt antal fängelse- och frihetsstraff i kombination med en generellt sett liberal och human kriminalpolitik samt en tämligen tolerabel brottslighetsnivå. I detta avseende har Norden på ett positivt sätt avvikit från de flesta andra områden.

Detta särdrag har också beskrivits av Michael Tonry i boken "Crime and Justice In Scandinavia" (2011). Jag citerar:

Compared with most developed countries, most strikingly the United States, Scandinavian criminal justice systems are and long have been humane. Citizens have confidence in the systems and its officials: their perceived legitimacy is high. Punishments are moderate, prisons are small and decent, and few people are locked up [...] Scandinavian approaches to crime and punishment offer important lessons to scholars, citizens, and policy makers in other countries. Their present may be our future. More ominously, if they succumb to xenophobic and populist political pressures that exist everywhere, our may be theirs. ${ }^{31}$

Vad var det som lade grunden för den nordiska exceptionalismen? Det var flera medverkande faktorer som alla hölls samman av uppfattningen att kontrollpolitiken och kriminalpolitiken skulle byggas på rationalitet, humanitet och en generell 
värdemedvetenhet. Detta återspeglades i de ideologier och teorier som blev förhärskande. Den nordiska kriminalpolitiken och straffrättspolitiken byggdes på två grundpelare: en defensiv kriminalpolitik och en nyklassisk syn på straffmätning och påföljdsval. Båda dessa grundpelare har rests med hjälp av grundläggande överväganden med avseende på frågan om vad som ska kriminaliseras och vilken straffrättens funktion ska vara. Här kan man inte undgå att nämna Nils Jareborg. ${ }^{32}$

Jareborg beskriver den defensiva modellen genom att framhäva följande kännetecken:

"[a]1l criminal law aims at protecting the interests of individuals, collective or public interests, or State interests, by using threats of punishment and by using execution of punishments to make the threat credible [...] The defensive model also aims at protecting individuals against power abuse, against abuse of State power, excessive repression in legal or illegal forms, as well as against abuse of private, informal power, of which "lynch justice" is the most obvious form.",33

Jareborg betonar särskilt att straffrätten inte har visa syften och att den inte ska användas för vissa ändamål. Straffrättens funktion är inte primärt att lösa möjliga sociala problem som finns i samhället, utan att reagera på oönskat beteende på ett moraliskt acceptabelt sätt. Genom den defensiva modellen realiseras kraven på en rationell och human kriminalpolitik. Den är också nyckeln till en nyklassisk syn på straffmätning och påföljdsval. Straffen ska stå i rättvis proportionalitet till brottet. Straffen ska inte användas som instrument för att framtvinga politiska eller sociala mål. En sådan instrumentell syn leder lätt till överstränga straff och en skadlig punitivism.

\section{7. "Nyklassicismen"}

Den nyklassiska synen slog först igenom i Finland genom nya bestämmelser om påföljdsbestämning som intogs i strafflagen år 1976. Bland dem fanns en allmän bestämmelse om straffmätning, bestämmelser om särskilda straffskärpnings- och strafflindringsgrunder samt en skälighetsbestämmelse vid påföljdskumulation. Enligt den allmänna bestämmelsen skulle vid straffmätning samtliga på saken inverkande straffskärpande och strafflindrande grunder samt enhetligheten i straffpraxis beaktas. Straffet skulle utmätas så att det stod i rättvist förhållande till brottets skadlighet och farlighet samt till den skuld gärningsmannen ådagalagt $\mathrm{i}$ brottet. Bestämmelsen gav uttryck för de ledande straffmätningsprinciperna, jämlikhet och proportionalitet.

På basis av förarbetena till reformen 1976 kan man sluta sig till att avsikten med den straffmätningsprövning som infördes var att tydligare och kraftfullare 
styra domstolarna i deras praxis. Syftet var att främja en enhetlig rättspraxis. Därför introducerade man en beslutsmodell för s.k. normalstrafftänkande. Enligt denna ska för normalbrott dömas till normalstraff, om det inte är motiverat att avvika från straffen i någondera riktningen. Genom normalstrafftänkandet försöker man förse straffmätningen med en utgångspunkt och en fixpunkt. Fixpunkten ska tas i rättspraxis. Domstolen bör hålla sig till de genomsnittslinjer som utgör vedertagen praxis, om tillfallet inte hänför sig någon särskild omständighet som ger domstolen rätt att avvika från linjen. ${ }^{34}$

Något senare realiserades den nyklassiska synen också i Sverige och i en ännu mera utarbetad form. Den svenska reformen förbereddes grundligt genom en utredning genomförd av Brottsförebyggande Rådet, BR $\AA,{ }^{35}$ av en omfattande offentlig utredning ${ }^{36}$ och en omfattande regeringsproposition. ${ }^{37}$ Senare har den nyklassiska synen också slagit igenom i de andra nordiska länderna, men inte alls i en lika ren form som i Finland och i Sverige. ${ }^{38}$

I Sverige antogs de nya bestämmelserna om straffmätning och påföljdsval 1989 genom att brottsbalken 29 kapitel och 30 kapitel ändrades. Härvid genomfördes ett tydligt tänkande i straffvärden. Varje brottstyp (delikt) har sitt abstrakta straffvärde som kommer till uttryck i straffskalan som ska användas och varje faktiskt brott har sitt eget konkreta straffvärde som man kommer fram till genom straffmätningen. Det hela bygger på en tillämpning av proportionalitets- och ekvivalensprinciperna. ${ }^{39}$

Påföljdsbestämningen består alltså av två delar, dels straffmätningen som leder fram till brottets straffvärde och sedan valet av påföljd mellan de alternativa påföljder som kan väljas. Fråga är om två skilda men av varandra beroende beslut med sikte på ett rationellt och rättvist avgörande. När det gäller påföljdsvalet är särskilt två bestämmelser riktgivande. Enligt brottsbalken 30 kap. $4 \S$ ska rätten vid val av påföljd fästa särskilt avseende vid omständigheter som talar för en lindrigare påföljd än fängelse. Därvid ska den bl.a. beakta alla omständigheter som kan tala för ett mildare straff än normalstraffet. Enligt brottsbalken 30 kap. $5 \S$ får fängelse bara utdömas i undantagsfall då fråga är om en gärningsman som inte fyllt 18 år. För att fängelse ska kunna komma ifråga krävs det synnerliga skäl. Då brottet har begåtts av en person som var under 21 år får fängelse bara utdömas om med hänsyn till gärningens straffvärde eller annars finns särskilda skäl för det. Motsvarande bestämmelser finns också i andra nordiska länder.

Bestämmelserna visar tydligt att andra påföljder än fängelse ska väljas då alternativ står till buds. Och en uppgift för lagstiftaren är att säkerställa att sådana alternativ finns. När det gäller de unga lagöverträdarna har man också skapat ett antal nya påföljder som uppfattas vara särskilt designade för de ungas behov. Det 
är ungdomsvård, ungdomstjänst och sluten ungdomsvård i Sverige, det är åtalsunderlåtelse i kombination med ungdomskontrakt och ungdomssanktion i Danmark, samt ungdomsstraff i Norge.

\section{Avkriminalisering och alternativa brottspåföljder}

Under 1900-talets sista decennier stod också möjligheterna av avkriminalisera brott och att ersätta de kriminalrättsliga påföljderna med administrativa påföljder i hög kurs. När det gällde en total avkriminalisering var det främst sedlighetsbrotten och sexualbrotten samt brott som återspeglade värderingarna bakom de gamla borgerliga dygderna som var i fokus. Också detta var uttryck för en rationell och human värdemedveten kriminalpolitik.

Under denna period avkriminaliserades också ett antal brott och en hel del brott flyttades över från det straffrättsliga systemet till det administrativa systemet. Det sistnämnda var särskilt fallet med avseende på trafikbrotten. Det kan noteras av ett av målen med den omfattande revisionen av den finska strafflagen, som inleddes redan år 1972 men avslutades först 1999, var att finna och realisera möjliga avkriminaliseringar. ${ }^{40}$ Dekriminalisering var vid denna tid en viktig kriminalpolitisk fråga i det mesta av Europa. År 1980 publicerade Europarådet den viktiga rapporten, Report on Decriminalization. ${ }^{41}$ I det långa loppet kanske detta inte blev så framgångsrikt som man hade hoppats. Tiden förändrades och strävandena att avkriminalisera ersattes av en iver att ny- och uppkriminalisera. Men mera om detta senare. Därtill kommer att de administrativa straffen visat sig vara betydligt mer problematiska än vad man hade utgått från, särskilt på grund av det förbud mot dubbel bestraffning som ingår i tilläggsprotokoll 7 artikel 4 till den Europeiska människorättskonventionen.

Under slutet av 1900-talet var det ett upplagt mål att hålla fångtalet lågt. Detta berodde på all den kritik som riktades mot fängelse som straff, allt från abolitionisternas totala förkastande av de kriminalrättsliga straffen ${ }^{42}$ till en mer moderat kritik av fängelsestraffen på grund av alla dess nackdelar. Ett gott belägg för de tankegångar som dominerade var Ulla Bondessons uppfattning. Efter att ha granskat forskningen om hur allmänpreventionen respektive individualpreventionen verkar och funnit att forskningsresultaten pekar på att den verkan som allmänpreventionen har är osäkra, visar på en noll-effekt och att effekterna av individualpreventionen t.o.m. är negativa konkluderar hon:

Själv har jag utifrån dessa resultat förespråkat en princip om minsta möjliga ingripande, kombinerad med en välfärdsideologi. Principen om minsta möjliga ingripande tar hänsyn till en tänkbar allmänpreventiv effekt eller tilltron till detta hos tongivande juridiska eller politiska grupper. 
Välfärdsideologin motiveras av de positiva resultat, som några studier visat vad gäller materiell hjälp i form av ekonomiska bidrag, hjälp till bostad och arbete.

Ett minskat bruk av fängelse i form av färre och kortare frihetsberövanden skulle kunna innebära en kraftigt utökad och förstärkt frivård samtidigt med både humanitära och finansiella besparelser. Att fängslande för de flesta intagna betyder ett stort mänskligt lidande torde institutionsforskningen väl ha demonstrerat. ${ }^{43}$

För att minska bruket av fängelse som straff försökte man finna vad som kallades "front-door och back-door-lösningar". Syftet med de förra var att hålla intaget $\mathrm{i}$ fängelse så litet som möjligt genom alternativ till frihetsstraff, medan syftet med de senare var att finna lösningar som möjliggjorde en så tidig utslussning som möjligt.

Endel sådana lösningar fanns sedan tidigare. Villkorliga (fängelse)straff hade tagits i bruk redan i början av 1900-talet. I Danmark öppnades möjligheterna för en villkorlig dom redan 1905, i Sverige infördes villkorlig dom 1906, medan möjligheten till villkorligt fängelse infördes i Finland 1918. Också möjligheten att bevilja åtalseftergift eller påföljdseftergift fanns, liksom den villkorliga frigivningen från ett frihetsstraff sedan en viss del av straffet hade verkställts i anstalt. I en nordisk utredning som genomfördes av Nordiska straffrättskommittén föreslog man 1978 gemensamma nordiska regler om villkorlig frigivning, men rekommendationen har aldrig realiserats fullt ut. ${ }^{44}$

Möjliga alternativ till frihetsstraff blev intressanta i försöken att begränsa fångtalet. Framför allt handlade det samhällstjänst och elektronisk övervakning med fotboja.

\section{Samhällstjänst}

Man kan säga att samhällstjänst som straffpåföljd är en produkt från 1970-talet. Möjligheten att döma till samhällstjänst växte betydligt fram i Europa sedan the Committee of Ministers of the Council of Europe i en resolution år 1976 (Resolution 76 (10) (March 1976)) uppmanade medlemsstaterna att undersöka möjliga fördelar med samhällstjänst. I Norden ledde det till att man under ett antal år hade prövoordningar med möjligheten att döma till samhällstjänst som tillägg till villkorligt fängelsestraff eller motsvarande. Senare har ordningen med samhällstjänst blivit permanent $i$ alla nordiska länder, men med ganska betydande variationer. ${ }^{45}$

I Danmark intogs bestämmelserna om samhällstjänst i strafflagen först 1992, efter försök som inleddes redan år 1982. Samhällstjänsten är kopplad till villkorlig dom i tillfällen då den primära - mest upplagda - straffet är ett fängelsestraff, som man vill undgå och då en villkorlig dom inte uppfattas vara tillräckligt 
sträng. Numera kan samhällstjänst också användas som ett villkor för villkorlig frigivning. Samhällstjänsten omfattning är minst 30 och högst 300 timmar arbete som ska utföras under den dömdes fritid under en period av 4 till 12 månader eller maximalt 2 år. Under denna tid är den dömde under Kriminalforsorgens tillsyn.

Samhällstjänst är i Finland ett allmänt straff som i stränghet placeras mellan villkorligt straff och ovillkorligt fängelse. Ordningen med samhällstjänst blev permanent år 1996 efter en prövoperiod som inleddes för en del av landet 1991 och för hela landet 1994. Samhällstjänst kan utdömas för ett brott som enligt normal påföljdsbestämning annars kunde bli högst åtta månader fängelse, samt därtill som tilläggstraff till ett fängelsestraff som är över ett år. Som tilläggstraff består samhällstjänsten av 90 timmar arbete, annars ligger timantalet mellan 20 och 200 timmar. Enligt tillgängliga uppgifter utdöms samhällstjänst i cirka 35\% av de fall som annars skulle föranleda högst åtta månader fängelse.

I Norge lancerades idén om samhällstjänst som ett alternativ till ovillkorligt fängelse i ett betänkande, den s.k. "Kriminalmeldningen" år 1978, men idén mötte så mycket motstånd att betänkandet drogs tillbaka och justitieministern avgick. På prov infördes samhällstjänst sedan år 1984 och ordningen blev efter goda erfarenheter permanent 1991. Samhällstjänst blev ett allmänt straff som i fråga om stränghet låg mellan villkorligt och ovillkorligt fängelse.

År 2001 ändrades lagstiftningen om samhällstjänst i Norge i samband med att man införde en ny lag om verkställighet av straff (straffegjennomføringsloven i 2001). Då infördes en ny sanktion, "samhällsstraff" (samfunnsstraff). Det nya straffet var en sammanslagning av den tidigare samhällstjänsten och villkorlig dom med tillsyn eller tillsynsprogram. Avsikten var att det nya straffet skulle få ett större användningsområde och ersätta ovillkorligt fängelse i andra fall än dem som gällde den grovare kriminaliteten. Samhällsstraff kan numera användas som straff för brott då det subsidiära straffet skulle vara ovillkorligt fängelse på högst ett år. Samhällsstraffets läng är 30 till 420 timmar som vanligen ska utföras under en tid som svarar mot det subsidiära ovillkorliga fängelsestraffet, men dock minst under 120 dagar.

En provordning med samhällstjänst inleddes i Sverige 1990 på fem orter i landet och pågick till 1992. Samhällstjänst var då kombinerat med påföljden skyddstillsyn. Efter detta följde ytterligare provordningar innan bestämmelserna om påföljden samhällstjänst år 1999 gjordes permanenta. Enligt den ordning som nu gäller är samhällstjänst en brottspåföljd som innebär att den dömde får en villkorlig dom om denne går med på att utföra oavlönat samhällsnyttigt arbete. Det utdömda arbetet kan variera mellan 40 och 240 timmar. Den som är under 21 år 
kan istället dömas till ungdomstjänst på mellan 20 och 150 timmar. Det är frivården som ansvarar för detta straff. Det alternativa fängelsestraffet anges alltid i domen och är mellan 14 dagar och upp till ett år. Genomförandet av arbetet ska ske på ungefär samma tid som det skulle ha tagit att verkställa det alternativa fängelsestraffet. Den som är dömd till skyddstillsyn står dessutom under övervakning.

Samhällstjänst infördes inte i Norden utan motstånd. Det krävdes också flera år av skilda ordningar då påföljden användes på prov. Påföljden blev inte heller ett självständigt straff utan det kopplades till en början alltid till ett villkorligt fängelsestraff eller motsvarande. Detta är fortfarande fallet, tydligast i Sverige. Samhällstjänst ansågs inte heller vara lämpligt för vissa brott, mest markant rattfylleri. I Danmark var orsaken till detta att samhällstjänst då skulle komma till användning $\mathrm{i}$ alltför många fall - så många att man inte administrativt kunde klara av detta. I Norge var orsaken en annan - här menade man att hänsyn till allmänpreventionen förhindrade det. I Finland har det största användningsområdet för samhällstjänst hela tiden varit som påföljd för grovt rattfylleri. ${ }^{46}$

Men numera har samhällstjänst blivit ett straff som erkänns vara gott och som används i stor utsträckning. Forskningen visar också att samhällstjänst är ett effektivt straff. Följande - ett forskningsresultat från Danmark - får illustrera detta:

Analyserne vedrørende effekten af sanktionerne viser, at risikoen for at recidivere er signifikant lavere blandt personer, der er idømt en betinget dom med vilkår om samfundstjeneste sammenlignet med dem, der er idømt en ubetinget frihedsstraf for alle de undersøgte recidivkriterier og for alle tre observationsperioder. Det vil sige, at personer, der er fundet egnede til samfundstjeneste, og som idømmes en sådan sanktion frem for en ubetinget straf, i ringere grad begår ny kriminalitet, der fører til en fældende strafferetlige afgørelse, i ringere grad begår kriminalitet, der fører til en betinget eller ubetinget frihedsstraf, og i ringere grad begår så alvorlig kriminalitet, at de får en ubetinget straf, end tilfældet ville have været, hvis de i stedet havde fået en ubetinget dom.

Konkret mindskes risikoen for overhovedet at recidivere med omkring 15 pct., når der idømmes samfundstjeneste $\mathrm{i}$ stedet for en ubetinget frihedsstraf. Risikoen for ny kriminalitet, som fører til en frihedsstraf, mindskes med omkring 25 pct., mens risikoen for at begå ny kriminalitet, der er så alvorlig, at det fører til en ny fængselsstraf, mindskes med 30 pct. i løbet af det første år efter dommen og med 39 pct. i perioden op til tre år efter dommen. ${ }^{47}$

\section{0. Övervakning med elektronisk fotboja}

Sverige var det första nordiska landet som införde elektronisk övervakning med fotboja. Elektronisk övervakning har använts sedan 1994, då den på försök infördes som ett sätt att verkställa korta fängelsestraff utanför anstalt. Från och med den 1 januari 1999 är försöksverksamheten permanentad, och numera kan fängel- 
sestraff upp till sex månader verkställas utanför anstalt genom intensivövervakning. För långtidsdömda kan elektronisk övervakning med fotboja utanför anstalten användas som ett led i frigivningen från verkställigheten i anstalt. Fotboja används också vid kontaktförbud för att säkerställa att den som dömts till kontaktförbud inte bryter mot förbudet.

Fotboja är i Sverige ett sätt att verkställa ett utdömt fängelsestraff. Det är inte domstolen som besluter om detta sätt för verkställighet, utan det är Kriminalvården som gör det efter ansökan. Till verkställigheten av elektronisk övervakning med fotboja hör ett antal villkor och ett antal övervakningsåtgärder.

Fotboja har numera också införts i andra nordiska länder. I Danmark infördes elektronisk övervakning med fotboja 2005. Till en början var det en ordning som erbjöds personer som dömts för rattfylleri samt personer som var under 25 år och som dömts för andra brott än rattfylleri. Senare har ordningen utvidgats betydligt och gäller sedan år 2013 alla personer som har dömts till ett fängelsestraff som inte överstiger 6 månader.

Under verkställigheten ska den dömda underkasta sig ett intensivt behandlings- och kontrollprogram. Det betyder bl.a. att han eller hon inte făr dricka alkohol eller använda droger. Kontrollbesök kan ske utan förvarning och den dömde kan också testas för narkotika och alkohol. Också behandlingsprogram mot missbruk kan ingå i verkställigheten. I Danmark är det Kriminalforsorgen som efter ansökan beviljar rätt till straffverkställighet med fotboja och hela ordningen ombesörjs också av dem.

I Finland infördes möjligheten att döma till övervakningsstraff med elektronisk fotboja år 2011. Fråga kan vara om ett straff för ett brott som annars skulle ha blivit fängelse på högst sex månader. Denna brottspåföljd var avsedd att förutom till ovillkorligt fängelsestraff vara ett alternativ till samhällstjänst då detta straff inte bedöms vara det riktiga. Det avsedda användningsområdet för övervakning med fotboja var främst egendomsbrott och rattfylleri. Men i praktiken har det visat sig att denna form för verkställighet inte används så mycket som man hade räknat med. Enligt uppgift beror det på är att de flesta som lämpar sig för straffet döms för rattfylleri, och det handlar om personer som inte klarar av det krav på total nykterhet som hör ihop med övervakningsstraff.

Tidigare ovillkorliga fängelsestraff och övervakningsstraff kan utgöra ett hinder för att ett övervakningsstraff kan dömas ut. Även brottets art kan utgöra ett hinder för användningen av övervakningsstraff. Till exempel misshandel som har riktats mot gärningsmannens sambo är sådana brott. Det finns också ett hinder för att döma ut ett övervakningsstraff i sådana fall där det är lätt för gärningsmannen 
att fortsättningsvis begå brott hemifrån eller på boplatsen. Sådana brott är till exempel narkotikabrott och vissa informations- och kommunikationsbrott.

I motsats till vad fallet är i Danmark och Sverige är det i Finland domstolen som dömer ut straffet övervakning med elektronisk fotboja. När åklagaren har beslutat väcka åtal för ett brott för vilket övervakningsstraff kan dömas ut, ska han eller hon av Brottspåföljdsmyndigheten inhämta en utredning av omständigheter som är av betydelse med tanke på dömande till övervakningsstraff. Sådana är till exempel den misstänktes personliga förhållanden och de övriga förutsättningarna för utdömandet av ett övervakningsstraff. På samma sätt som i de andra nordiska länderna är övervakningen kopplad till ett antal villkor och kontrollåtgärder.

En "fodlæankeordning" infördes i Norge år 2005. Denna ordning har samma drag som i de andra nordiska länderna och den centrala myndigheten är också här Kriminalforsorgen, alltså den centrala kriminalvårdsmyndigheten.

Både i Danmark och i Sverige har elektronisk övervakning med fotboja fått en stor användning. Men det betyder inte att kritik inte har riktats mot denna form för verkställighet av fängelsestraff. Kritiken har gällt att kraven på den dömde att vara punktlig är mycket stränga, med få ursäkter för att bli försenad under sina resor mellan arbete och hem, att övervakningen är mycket intensiv och integritetskränkande och att förbudet att dricka alkohol och använda droger är mycket strikt. Också fotbojan som alternativ har därför mött motstånd, speciellt till en början.

Man kan fråga sig varför man var så skeptisk i Norden både till samhällstjänst och till elektronisk övervakning med fotboja. Det fanns flera orsaker. En gemensam orsak var att man hyste tvivel om påföljderna var tillräckligt effektiva för att ersätta fängelse. Till en del var det ideologiska orsaker: ifråga om samhällstjänsten kunde man mena att det inte var lämpligt att döma personer som varit långtidsarbetslösa och sökt jobb till arbete nu när de hade begått ett brott. Också fackföreningarna var tveksamma på grund av att vissa arbetstillfällen som annars kom de arbetsflitiga till godo nu gick till brottslingar. När det gällde övervakning med fotboja uppfattades det som översitteri att förbjuda människor att njuta av alkohol i sitt eget hem.

Men orsakerna till motståndet var i hög grad kriminalpolitiskt motiverade. Vad man var rädd för var "net widening", alltså att de nya påföljderna inte skulle ersätta fängelse utan bli ett tillägg till fängelse. Detta önskade man förhindra bl.a. genom de försiktighetsmått för användningen av både samhällstjänst och övervakning med fotboja. 


\section{Fångtalet}

Särskilt i Finland var strävandena att minska fångtalet mycket medvetna - och med tiden också framgångsrika. Mellan år 1950 och 2000 sjönk fångtalet i Finland från cirka 190 fångar/100.000 invånare till cirka 50. Medvetenhet byggde på att bland ledande kriminalpolitikera vid observation av vilka personer det var som fanns i fängelserna drog konklusionen att där fanns personer som inte borde finnas där. Framgången berodde på normalstrafftänkandet och en ökad användning av åtalseftergift, villkorligt fängelse och böter för ett stort antal vardagsbrott i stället för fängelse. Också i de andra nordiska länderna bibehölls ett lågt fångtal, cirka 50 till 70 fångar per 100.000 invånare. Det var detta som berättigade att tala om "nordiska exceptionalismen".

Det har ofta väckt en förundran att fångtalet i Finland verkligen sjönk så drastiskt. Vad berodde det på? Tapio Lappi-Seppälä har gett följande förklaring:

The decrease in the Finnish prison population has been a result of conscious, long term and systematic criminal policy. [But ... what] all made this possible?

Part of the answer could be found in the structure of our political culture. The Finnish criminologist Patrik Törnudd has stressed the importance of the political will and consensus to bring down the prisoner rate. As he summaries, those experts who were in charge of planning the reforms and research shared an almost unanimous conviction that Finland's internationally high prisoner rate was a disgrace and that it would be possible to significantly reduce the amount and length of prison sentences without serious repercussions on the crime situation. ${ }^{48}$

Det finns allt skäl att också notera den utveckling som har funnits i Norden när det gäller kriminalvården och kriminalvårdsanstalterna. De öppna och halvöppna anstalterna utökades för att skapa drägligare villkor för verkställighet av fängelsestraff. Kriminalvården moderniserades och humaniserades på ett sätt som också har mött kritik. Fängelserna påstods ha blivit bekväma semesterhem. Men samtidigt har man också byggt och inrättat mycket slutna anstalter med stora säkerhetsföranstaltningar. Också det något som har mött kritik, men av motsatta skäl.

Här ska mycket kort också nämnas strävandena att införa olika former för medling. Medlingstanken har förts längst i Norge, där man inrättat särskilda konfliktråd till vilka behandlingen av ett brott kan överföras från de allmänna domstolarna. I Sverige har man infört möjligheten till medling vid brott genom en särskild lag, lag (2002:445) om medling med anledning av brott. Sedan år 2008 är alla svenska kommuner skyldiga att erbjuda medling till lagöverträdare under 21 år, men medling är i och för sig inte begränsat till den grupp av personer som begått brott. Men i Sverige ersätter medlingen inte automatiskt åtal och rättegång 
vid allmän domstol; En framgångsrik medling kan beaktas. I Danmark är konfliktmægling oreglerat och har inte någon nämnvärd betydelse.

I Finland regleras medling vid brott genom lagen om medling vid brott och i vissa tvister (2005). Här kan medling ske i fråga om brott som bedöms vara lämpliga för medling med beaktande av brottets art och tillvägagångssättet, förhållandet mellan den misstänkte och brottsoffret samt övriga omständigheter som helhet. Medling får inte ske i brott mot minderåriga, om offret på grund av brottets art eller sin ålder är i behov av särskilt skydd. En framgångsrik medling kan beaktas vid beslut om åtal, beslut om domseftergift och vid straffmätningen.

\section{Men ingenting varar evigt: 1990 -talet framåt: Det nordiska samarbetet förändras och försvagas, straffrätten blir europeisk}

Någon gång på 1990-talet bröts den tidigare kriminalpolitiska trenden som betonade behovet av minskad repression. Det som kom i stället var en tydlig punitivistisk attityd. Den nya trenden syntes först i Sverige genom Justitiedepartementets skrift "Att renovera en förfallen kriminalpolitik". Bakom skriften stod den dåvarande borgerliga regeringen, men de andra partierna mötte snart upp i tropp med krav om strängare tag mot brottsligheten. Också i Danmark gjorde man i början av 1990-talet upp med den tidigare liberala kriminalpolitiken - detta skedde bl.a. genom att politikerna tog klart avstånd från den kriminalvetenskapliga sakkunskapen. "En god kriminalpolitik behöver inte smakdomare utan tillräckligt sträng konsekvens".

Ett markant inslag i kriminalpolitiken blev nu också det som träffande har kallats "signallagstiftning". Med detta avses ny strafflagstiftning vars primära funktion är att "sända signaler". I en artikel har Thomas Elholm analyserat denna form för lagstiftning och beskriver dess funktioner (med hänvisning till Flemming Balvig) genom att ange följande kännetecken: lagstiftningen har en "handlingsfunktion" - den ska på ett enkelt, synligt och lättförstått sätt signalera att "man gör nånting" åt något som uppfattas som ett problem. Kriminaliseringen ska också ses som en avledningsmanöver: den ska avleda uppmärksamheten från samhällsförhållanden som skapar aggresion genom att stöta ut en eller flera samhällsgrupper ("dom" som syndabockar). Och slutligen har kriminaliseringen en renovationsfunktion: den ska rensa gatubilden från oönskade element genom att inspärra dem. $^{49}$

Den nya trenden innebar flera förändringar. En klar ideologisk förändring var att man övergav den defensiva straffrättspolitiken och gick in för en offensiv politik. Gott stöd för detta fick man av EU och EU:s kamp mot brottslighet och brottslingar. Mer konkret innebar det nya kriminaliseringar, i Sverige förutom 
olika terroristbrott också kriminalisering av barnpornografi och köp av sexuell tjänst. Det senaste tillskottet i Sverige (och numera också i Danmark) är nykriminaliseringen av sex med djur, alltså tidelag. De andra nordiska länderna, med undantag för Danmark, har senare följt i Sveriges spår när det gäller kriminaliseringen av köp av sexuell tjänst, medan strängare straff för barnpornografi har införts i alla nordiska länder - inte minst efter krav från EU. Straffen för många brottstyper höjdes markant. Detta gällde i Danmark och Norge för narkotikabrotten, $\mathrm{i}$ alla nordiska länder för våldsbrotten och sexualbrotten, och då särskilt våldtäkt.

I domspraxis steg straffen för flera kategorier av brott och fängelsestraff blev ett allt vanligare straff. Detta uppmärksammades också internationellt. I en bok publicerad år 2006 skrev John Pratt:

In Finland, and in the other Scandinavian countries, prison populations are increasing, notwithstanding that they still remain some significant distance behind most other Western countries; from a rate of 55 persons of 100.00 of population in 1998 to 74 in Finland in 2005; from 56 to 68 in Norway 69 to 78 in Denmark 58 to 78 in Sweden. At the time, their unique welfare arrangements have also been cut back (although not fundamentally redrawn). ${ }^{50}$

Pratt anger att de viktigaste orsakerna till det stigande fångtalet var "[c]hanging attitudes to drug, sexual and violent crime". Denna utveckling innebar att fångtalet steg i alla nordiska länder, mest i Sverige där fångtalet på några få år steg från under 60 fångar/100.000 invånare till över 80 fångar. Också användningen av fängelsestraff på livstid har ökade där markant, från 105 år 2001 till 155 år 2012.

Hur kan denna förändring förklaras? Trots att det inte är en förklaring i sig är det symptomatiskt att förändringen skedde medan det nordiska straffrättsliga samarbetet minskade och EU-inflytandet ökade. Och EU:s "kriminalpolitik" har inte stora likheter med den tidigare nordiska kriminalpolitiken. Den bygger för det första på EU:s fyra friheter, frihet, säkerhet och rättvisa. Och här ges begreppet frihet en innebörd som är mycket vid och bl.a. innefattar människornas rätt att leva i ett samhälle fritt från brott och brottslingar. Detta leder till att en starkt straffrättslig repression inte bara tolereras utan förutsätts.

EU-straffrätten har blivit omfattande och betydelsefull. Den bygger visserligen i första hand på rättsligt samarbete, men också harmoniseringen av den materiella straffrätten har en stor betydelse. Harmoniseringen bygger dels på tillnärmningen av de nationella strafflagarnas brottsrekvisit och dels på krav om tillräckligt stränga brottspåföljder. Det senare genomförs genom att uppställa krav på vilket minimum straffmaximum ska ha. Som en följd av detta har straffmaximum 
höjts i de nordiska länderna för flera brottstyper. Hur stor betydelse detta har haft och hur väl det harmonierar med ett möjligt allmänt rättsmedvetande kan diskuteras. $^{51}$

Vad som är särskilt viktigt är att EU-straffrätten bygger på en annan ideologi än den tidigare nordiska kriminalpolitiken. Straffrätten uppfattas inte vara ett normativt system utan målsättningen är att realisera särskilda politiska och sociala mål. EU straffrätten är ett medel för att säkerställa unionens politik på alla områden som omfattas av harmoniseringsåtgärder för att kunna genomföra dem effektivt. I EU språkbruket talar man inte heller om att kontrollera brottsligheten, utan om att bekämpa brottsligheten och de personer som står för den. Läran om brottslighetens nödvändighet som varit en del av den nordiska kriminalpolitiska kontrollen har inte längre någon relevans. I stället går man in för en lösning som markerar nolltolerans mot alla dem som genom brott kränker friheten att leva i ett brottlöst samhälle.

En förklaring som har haft en stor betydelse för utvecklingen i Sverige är offerrörelsen. Offren har fått allt flera rättigheter och också allt större betydelse som aktiv kriminalpolitisk aktör. Flera av straffskärpningarna har skett efter krav från offerrörelsen. Detta gäller inte minst för våldsbrottens och sexualbrottens vidkommande.

Många har uppfattat den kriminalpolitiska utvecklingen i Norden under 1990talet och början av 2000-talet som ett tydligt förfall. Jag hör själv till dem som har kritiserat denna utveckling, men den kritiken ska jag inte upprepa här. ${ }^{52}$ I stället citerar jag Vagn Greve i den avskedsföreläsning som han år 2008 höll när han lämnade professuren i straffrätt vid Köpenhamns universitet:

"For knap 16 år siden holdt jeg min tiltrædelsesforelæsning om "Aktuelle strafferetlige spørgsmål”. Jeg har fundet den frem og synes faktisk, at den er vældig fornuftig. Desværre er så godt som alle (!) de i dén nævnte problemer fortsat i mindst så høj grad problemer i dag. Det vil jeg gerne fralægge mig ansvaret for. Der er alt for mange træk i nutiden, som viser, at den humane, empirisk funderede, retsstatslige strafferet, som mine forgængere (Torp, Hurwitz og Waaben) og jeg efter evne har søgt at fremme, er trængt. Bevares, verden går under på en meget stilfærdig måde i Danmark [...]. Men nedbrydningen sker lige vel gennem erosioner som gennem eksplosioner. Det er fortsat sådan, at det bedste overblik over verden får man fra "elfenbenstårnet", og synet derfra giver mig kuldegysninger. Der kan fremføres særdeles gode argumenter for, at de samme 16 år udviklingsmæssigt set har været de værste år for strafferetten i de seneste 200 år. Medens perioden fra 1770 til 1990 stort set var velbegrundet "Zug zur Milde", har det siden været et ubegrundet Zug zur Strenge. Og det vil jeg i hvert fald fralægge mig ansvaret for. Jeg tror heller ikke, at nogen politiker vil føle trang til at lægge det over på mig.",53 


\section{Och nu: Vart har alla fångar tagit vägen?}

Men efter 2005 har nånting hänt. Fångtalet har börjat sjunka. Detta är särskilt tydligt i Danmark och i Sverige. Tillgängliga uppgifter visar antalet personer intagna i kriminalvårdsanstalt i Sverige den 10 oktober åren 2010-2014. I Sverige har antalet fångar den 1 oktober sjunkit från 5.374 år 2010 till 4.319 år 2014, alltså en faktisk minskning med över tusen personer. Denna minskning har skett i alla åldersgrupper, men minst för dem som är över 55 år. Störst är minskningen för dem som är mellan 21 och 44 år.

Den intressanta frågan är vad som förklarar denna minskning. Åter igen finns flera förklaringar. En förklaring är att brottsligheten de facto har minskat och därigenom också antalet lagföringar. År 2013 var antalet lagförda personer totalt 130.134 och detta var en minskning på ett år med cirka 13.500. En annan förklaring är att alternativ till fängelsestraff åter används något mer. Fördelningen mellan de viktigaste påföljderna år 2013 var följande: ${ }^{54}$

Böter 31.162, åtalsunderlåtelse 17.596, fängelse 11.212, villkorlig dom 10.512, skyddstillsyn 6.414, påföljden fastställs ingå i tidigare utdömd påföljd (BrB 34.1 p. 1) 1.820, ungdomstjänst 1.492, ungdomsvård 1.408, överlämnande till rättspsykiatrisk vård 284, sluten ungdomsvård 42, påföljdseftergift enligt $\mathrm{BrB}$ 29:6 och 30:6 37 och överlämnande till vård av missbrukare 8 .

Det är intressant att notera antalet åtalsunderlåtelser som här uppgår till c 17.500. Under 2000-talet har detta tal tecknat en berg- och dalbana. Antalet utfärdade åtalsunderlåtelser minskade från 1975 framåt, men denna trend bröts efter år 2005, då antalet åtalsunderlåtelser började öka. Ökningen fortsatte till och med år 2009. Mellan åren 2005 och 2009 handlar det om en volymökning med omkring 10.000 åtalsunderlåtelser, från 16.250 år 2005 till 26.823 år 2009. Efter 2009 började antalet åtalsunderlåtelser minska igen; mellan åren 2009 och 2012 handlar det om en minskning med omkring 5.000 åtalsunderlåtelser till 21.752 år 2012, och också efter det har antalet minskat. ${ }^{55}$

I en kortrapport publicerad 2014 försöker BRÅ analysera orsakerna till denna fluktuation. Resultaten i kortanalysen pekar på att det inte är någon enskild faktor som kan förklara utvecklingen av antalet åtalsunderlåtelser. I stället är det flera olika mekanismer som bedöms bidra. Utvecklingen har påverkats av främst tre övergripande faktorer: förändringar i inflödet av anmälda brott, förändrade påföljdsval för unga samt förändrade arbetssätt hos både polis och åklagare. Exakt hur stor betydelse varje faktor har haft går dock inte att säga. ${ }^{56}$

Relativt många fängelsestraff utdöms fortfarande, men fängelsestraffen är överlag ganska korta. Detta kan visas i en tabell: 


\begin{tabular}{|lr|}
\hline Fängelse högst 6 månader & $71 \%$ \\
\hline [Av dessa fängelse högst 2 månader, och & $47 \%$ \\
\hline fängelse över 2, högst 6 månader] & $24 \%$ \\
\hline Fängelse högst 2 år & $21 \%$ \\
\hline Fängelse över 2 år & $8 \%$ \\
\hline
\end{tabular}

Också i Danmark har antalet fångar sjunkit. Detta är tydligt särskilt när det gäller år 2014 och 2015. Den genomsnittliga dagliga beläggningen har under de fyra senaste åren sjunkit med flera hundra fångar. Orsaken till detta är uppenbarligen en viss minskning av kriminaliteten och en tydlig ökning av dem vars frihetsstraff verkställs genom elektronisk övervakning med fotboja.

Enligt uppgifter syns motsvarande trend i Finland, medan utvecklingen i Norge har varit den motsatta. Antalet fångar har ökat så mycket att fängelsesituationen har blivit akut. År 2014 stod 1.300 fångar i kö för att avtjäna sitt fängelsestraff och det kan den norska kriminalvården inte klara av. Man har därför tagit initiativ för att hyra fängelseplatser först av Sverige och då den begäran avslogs av Nederländerna.

\section{Banbrytare eller eftersläntrare?}

I min titel ställde jag en fråga: Har de nordiska länderna varit banbrytare eller eftersläntrare när det gäller kriminalpolitiken? Efter den granskning som jag gjort med en tidsaspekt på 100 år skulle det vara på sin plats med ett entydigt svar. Men det kan jag inte ge. Eller det blir ett typiskt försiktigt juristsvar: "Nja ... både ock".

Det gick långt in på 1900-talet innan Norden på något sätt gjorde sig internationellt bemärkt på det kriminalpolitiska området. De rashygieniska strömningar som fanns särskilt under 1930-talet var lån särskilt från Tyskland, ja till och med till en del inspirerade av nazismen. Kriget var som andra krig en olycklig period också för samhällelig kontroll och utan möjlighet till sociala reformer. Efterkrigstiden kännetecknades av en ökande optimism, ett ökat arbete för ett välfärdssamfund, en viss reformiver med avseende på straffrätten och kriminalpolitiken, men också av en starkt ökande brottslighet. Positivt var det ökade nordiska samarbetet på straffrättens och kriminalpolitikens område. Detta ledde till att Norden också internationellt sett ofta framhävdes som en region med väl utvecklat rättsligt samarbete och som en följd av detta med goda resultat. Höjdpunkten kom under "the Golden Age of Nordic co-operation" och de ideologiska rörelser som betonade brottslighetens nödvändighet, nödvändigheten av ett cost- benefit-tänkande 
också då det gäller kriminalitetskontroll, den humana, empirisk baserade, rättsstatliga straffrätten och en straffideologi som bygger på en nyklassisk syn. Det ska i alla fall noteras att Norden inte var föregångare då det gällde att ta i bruk samhällspåföljder som alternativ till fängelse och inte heller när det gällde avkriminalisering

Men denna era som föregångare på det kriminalpolitiska området tog slut, liksom den nordiska samsynen på och samarbetet kring brottslighetskontrollen. Norden har inte varit en progressiv region när det gäller en rationell kriminalpolitik inom EU. De nordiska medlemsländerna har i många avseenden varit lydiga medlemsländer utan intresse eller förmåga att leda utvecklingen inom EU.

Det intressanta är vad som sker nu med sjunkande brottslighet och sjunkande fångtal. Kan vi möjligen vara optimistiska och igen återfå en tro på en rationell, evidensbaserad och human brottslighetskontroll.

\section{Noter}

1. Kriminalistföreningen i Finland grundades 1934. Den 23 april 2015 arrangerades ett jubileumsseminarium i Helsingfors med anledning av att 80 år hade förflutit sedan grundandet. Denna text är en bearbetad version av det föredrag som författaren höll vid seminariet.

2. Per Ole Träskman (LL.D., doctor hc.) is senior professor of Criminal Law at the University of Lund (Sweden) and associate professor of criminal law and criminal procedure at the University of Helsinki.

3. Se beträffande detta genombrott och den debatt som fördes av kriminalister vid denna tid i Danmark Peter Garde: August Goll - en shakespearsk kriminalist og hans tid. Jurist- og Økonomforbundets Forlag 2012.

4. Per Ole Träskman: Finsk, svensk och nordisk straffrätt - och den europeiska- några reflektioner. Tatu Hyttinen ym (Toim.): Rikosesta rangaistukseen. Juhlajulkaisu Pekka Viljanen 1952-26/8-2012. Turun yliopiston oikeustieteellisen tiedekunnan julkaisuja. A. Juhlajulkaisut N.o 25. Turku 2012, s 257-270.

5. Brottsligheten och möjligheterna för dess bekämpande. Föredrag hållna under antibrottslighetsveckan i Helsingfors den 7-13 januari 1934. Utgivna av kommittén för veckans anordnande. Helsinki 1935.

6. R.A. Wrede: Brottsligheten och dess bekämpande. A.a., s 123-125.

7. Två av föreläsningarna under antibrottsveckan handlade om sterilisering. Det var Harry Federley: I sterilisationsfrågan (se i fotnot 4 a.a., s 170-190 och Brynolf Honkasalo, Om sterilisering, a.a. s. 191-227. Enligt Peter Garde var årgång 1935 av Nordisk Tidskrift for Kriminalvidenskab fylld med artiklar om sterilisering och tvångskastrering. Peter Garde: Nordisk Tidskrift for Kriminalvidenskab 1913-2013. NTfK 2013, s 17.

8. Olof Kinberg: Den svenska lagstiftningen mot alkoholmissbruket (i fotnot 4 a.a., s. 107122 och Om medicinska åtgärder för brottslighetens förebyggande (ibidem, s 141-169; Harry Federley: Brottsligheten som biologisk företeelse (ibidem, s 8-33 och I sterilisationsfrågan, ibidem s 191-227. 
9. Kinberg: Varför blir människor brottsliga (1935), s 93.

10. Olof Kinberg: Om s.k. lösdrivare och deras behandling. Social-medicinsk studie. Stockholm 1924, s 29.

11. http://sv.wikipedia.org/wiki/Harry_Federley

12. Ibidem, s 29-34.

13. Olof Kinberg: Se i fotnot 4 a.a. s 107-122.

14. Olof Kinberg: Aktuella kriminalitetsproblem i psykologisk belysning (se fotnot 4), s 353 .

15. Se Britta Kyvsgaard: 100 års nordisk kriminalpolitik. Inlæg ved Svenska Kriminalistforenings 100-års jubilæum. NTfK 2012, s 128-135. Att det också fanns "ett öppet intellektuellt klimat" under mellankrigstiden har beskrivits av Sten Levander: God vilja räckte inte - ett personligt perspektiv på svernsk rättspsykiatri. NTfK 2011, s 59-70.

16. Kyvsgaard a.a. s. 128-135.

17. Hannu Takala og Henrik Tham (red.): Krig og moral. Kriminalitet og kontroll i Norden under andre verdenskrig. Universitetsforlaget, 1987.

18. Henrik Tham: Stöldutvecklingen under kriget som moralindikator. I fotnot 15 a.a., s 301308.

19. Heikki Ylikangas: Romahtaako rintama. Otava 2007. Ylikangas uppger att cirka 250 finska soldater avrättades bara under fortsättningskriget 1941-44 på grund av fanflykt eller uppmaning till fanflykt. Till detta kom ett okänt antal avrättningar på andra grunder. Ylikangas kritiserades omedelbart för sina beräkningar särskilt från militärt håll - enligt officiella armékällor var antalet betydligt mindre.

20. Per Ole Träskman: Om dödsstraffet: "... och det finns endast ett straff som står i rättvist förhållande till en sådan förbrytelse" I Festskrift till Hans-Heinrich Vogel. Juristförlaget 2008, s 427-445.

21. Se NTfK 1984 nummer 2.

22. Flemming Balvig: Kriminalitetens udvikling i Danmark 1950-82. NTfK 1984, s 83-108.

23. Sturla Falck: Kriminalitetsutviklingen i Norge fra 1950-årene til 1980-årene. NTfK 1984, s 126-148.

24. Patrik Törnudd: Kriminalitetsutvecklingen i Finland 1950-1982. NTfK 1984, s 149-168.

25. Lawrence E Cohen \& Marcus Felson: Social Change and Crime Rate Trends: A Routine Activity Approach. American Sociological Review 1979, Vol. 44, s 588-608.

26. SOU 1956:55. Strafflagsberedningens betänkande.

27. Britta Kyvsgaard i fotnot 14 a.a. s 130.

28. Heikki Pihlajanmäki: 1900-luvun rikosoikeudellisia kehityslinjoja. I Pia Letto Vanamo (toim.): Suomen oikeushistorian pääpiirteet. Sukuvallasta moderniin oikeuteen. Gaudeamus 1991, s 282-285.

29. Per Ole Träskman:'The Golden Age of Nordic Cooperation". Har de nordiska kronjuvelerna kommit på museum? - Den nordiska brottskontroillen: nutid, dåtid och framtid. NTfK 2013, s 333-355. Se också Christoffer Wong: Nordic cooperation in criminal matters. I Ulrika Andersson m.fl. (red.) Festskrift till Per Ole Träskman. Norstedts Juridik 2011, s 542549.

30. Ibidem, s 334 med hänvisning till John Pratt och Anna Eriksson: Den skandinaviska exceptionalismen i kriminalpolitiken. NTfK 2009, s 135-151. 
31. Michael Tonry: Preface. I Michael Tonry \& Tapio Lappi-Seppälä (Ed.) Crime and Justice in Scandinavia. The University of Chigaco Press,. Chigaco and London (2011), s viii-ix.

32. Per Ole Träskman: Finsk, svensk och nordisk straffrätt - och den europeiska - några reflektioner. I Tatu Hyttinen (toim.): Rikoksesta rangaistukseen. Juhlajulkaisu Pekka Viljanen 1952-26/8 - 2012. Turun yliopiston oikeustieteellisen tiedekunnan julkaisuja. A. Juhlajulkaisut N:o 25. Turun yliopisto 2012, s 257-270.

33. Jareborgs artikel om defensiv och offensiv kriminalpolitik var ursprungligen skriven på svenska, se Nils Jareborg: Defensiv och offensiv kriminalpolitik. NTfK 1994 s 41-53. Den engelska versionen fick en större internationell spridning.

34. Se Regeringsproposition RP 44/2002, s 171.

35. BRÅ Nytt straffsystem: Idéer och förslag. Liber Förlag 1977.

36. Fängelsestraffkommittén tillsattes 1979 och den lämnade sitt huvudbetänkande, Påföljder för brott, 1986 (SOU 1986:13-15.

37. Prop.1987/88:120.

38. Se Vagn Greve: Straffene. Jurist- og Økonomforbundets Forlag, 2 udg. 2002, s 231-250.

39. SOU 2008:85. Straff i proportion till brottets allvar.

40. Raimo Lahti: Pekka Koskinen in memoriam. I Raimo Lahti (toim.): Rikosoikeuden muutos 1960- luvulta 2010-luvulle. Pekka Koskisen (1943-2011) muistojulkaisu. Helsingin yliopiston oikeustieteellisen tiedekunnan julkaisuja 2013, s XI-XII.

41. Council of the European Union, Report on Decriminalization, Strasbourg 1980)

42. Se Per Ole Träskman: Fängelse - allas vårt favoritstraff. SvJT 2010, s 529-544.

43. Ulla Bondesson: Kriminalitet och straff. I Britta Kyvsgaard, Preben Wilhjelm \& Jacob Hilden Winsløw: Kriminologiske bidrag til 80'ernes kriminalpolitiske debat. Kriminalistisk Instituts stencilserie Nr. 38. (1986), s 113-120.

44. Nordiska straffrättskommittén: Villkorlig frigivning. 1978. Betänkandet och dess förslag samt utvecklingen efter detta behandlas i Helén Örnemark Hansen: Nio år i Danmark blir sex i Sverige? - En diskussion om villkorlig frigivning. I Ulrika Andersson m.fl. (red.): Festskrift till Per Ole Träskman. Norstedts Juridik 2011, s 557-563.

45. Nordisk Tidskrift for Kriminalvidenskap hade ett nummer med särskild fokus på samhällstjänst och andra motsvarande påföljder (2001 nummer 2 "Samfundssanktioner i Norden"). En del av informationen i detta nummer är tyvärr numera föråldrat.

46. Greve: I fotnot 37 a.a. s 131.

47. Christian Klement og Anne-Julie Pedersen: SAMFUNDSTJENESTE. En udvidet effektevaluering. JUSTITSMINISTERIETS FORSKNINGSKONTOR. MAJ 2014.

48. Tapio Lappi-Seppälä: Reducing the Prison Population - Long-term Experiences from Finland. I Ulla V. Bondeson (Ed.): Crime and Justice in Scandinavia. Forlaget Thomson 2005, s 382-402.

49. Thomas Elholm: Rimer signal på kriminal? - Om symbol- og signallovgivning i dansk kriminalpolitisk perspektiv. I Ulrika Andersson m.fl. (red.): Festskrift till Per Ole Träskman. Norstedts Juridik 2011, s166-178.

50. John Pratt: Penal Populism. Routledge 2007, s 169.

51. Se Thomas Elholm: Danskarnas retsfølelse - og EU. I Britta Kyvsgaard m.fl. (red.): Kriminalistiske pejlinger. Festskrift til Flemming Balvig. Jurist- og Økonomforbundets Forlag 2015, s 81-96. 
52. Per Ole Träskman $i$ i fotnot 28 a.a.

53. Vagn Greve: Juridiske konflikter. Afskedsforelæsning den 28nde marts 2008. Københavns universitet 2008, s 29.

54. BRA. Statistik. Personer lagförda (dömda m.m.) för brott 2013.

https://www.bra.se/bra/brott-och-statistik/statistik/personer-lagforda-for-brott.html.

55. Utvecklingen för åtalsunderlåtelser under 2000-talet. BRÅ Kortrapport 2014.

56. Ibidem. 